\title{
Mechanisms of asbestos carcinogenesis and toxicity: the amphibole hypothesis revisited
}

Inhalation of asbestos in various industrial settings has been associated with the development of lung cancers and malignant mesotheliomas of the pleura and peritoneum. It has become increasingly clear within the past few years that the prevalence of mesothelioma varies considerably according to fibre type-the highest incidence of tumours being reported in workers exposed to crocidolite or mixed exposures of crocidolite and chrysotile. ${ }^{1}$ Exposures to amosite in the presence and absence of chrysotile also have resulted in less striking increases in pleural and peritoneal mesotheliomas. ${ }^{12}$ Of current debate is whether or not the mesotheliomas reported in chrysotile miners and millers in Quebec can be attributed to tremolite or other amphibole fibres existing in the Thetford and Asbestos mining areas. ${ }^{3}$ Based on findings from a compendium of epidemiological studies, ${ }^{4}$ the "amphibole hypothesis" was advanced to provide a mechanistic framework for the increased pathogenicity of the amphiboles, crocidolite and amosite asbestos, in the causation of human mesothelioma. ${ }^{5}$ According to this theory, an important but not exclusive factor in asbestos carcinogenesis is the durability of fibres in pleura or lung over the extended latency periods of tumour development averaging 35 to 40 years in humans. Thus in comparison with chrysotile fibres that appear to dissolve or fragment over time, amphibole asbestos may persist at sites of tumour development and serve as a chronic, necessary stimulus for neoplastic growth. Experimental evidence in support of this concept comes from the earlier work of Brand and colleagues exploring the mechanisms of "foreign body carcinogenesis", a phenomenon in which plastic films or other foreign bodies cause sarcomas when implanted subcutaneously into rodents. ${ }^{6}$ In this model, tumours fail to develop if the implant is removed before a critical period of time.

In recent years, important advances have been made toward understanding the molecular mechanisms of asbestos induced carcinogenesis and toxicity. The cytotoxic, genotoxic and proliferative effects of asbestos seem to be mediated in part by active oxygen species, reactive metabolites of oxygen that are produced from phagocytic cells, particularly in response to long $(>5 \mu)$ carcinogenic fibres, or catalysed by iron on the fibre surface. Thus the needle like configuration and durability as well as increased iron content of crocidolite, in comparison with amosite or chrysotile, may govern its ability to produce chronic inflammation and proliferation, events that may be coupled to its increased pathogenicity. Highlights of relevant studies are summarised here.

Carcinogenesis is conventionally regarded as a series of events that begin with initiation of genetic alterations by an agent(s) that interacts with DNA and causes heritable alterations. Cells bearing oncogenic mutations then require a stimulus to divide during the extended period of tumour promotion and progression. The long latency time between initiation and diagnosis of disease may reflect the findings from many experimental models that multiple genetic changes are required for the development of tumours. For example, non-random cytogenetic alterations have been found in human mesotheliomas including losses of chromosome 4, 22, and 9p and increases in chromosomes 5,7 and $20 .^{7-9}$ Chromosome $3 p$ and $17 p$ deletions occur often in these and other tumour types.

Searches for mutations in conventional oncogenes (ras, $m y c$ ) that may be activated as a result of asbestos induced chromosomal changes have proved negative. Moreover, few alterations in tumour suppressor genes ( $p 53$, retinoblastoma) in which deactivation is critical to the initiation or development of other neoplasms have been found in human mesotheliomas. These experiments are limited by the complexity of genetic changes seen in human tumours and the possibility that unique genes or cooperative interactions between genes may be important in the development of tumours. In a preliminary report, three of four human mesothelioma cell lines showed $p 53$ gene alterations that have been documented in other tumours including lung carcinomas. ${ }^{1011}$ Examination of 20 mesothelioma cell lines from 17 patients exhibited $p 53$ abnormalities in only three lines however and there was no evidence of $\mathrm{Ki}$-ras activation. ${ }^{12}$

Traditional approaches of identifying asbestos induced oncogenes by rodent transformation assays have been inconclusive. For example, transfection 
of murine NIH/3T3 cells with DNA from a human mesothelioma showed that the transforming DNA was not homologous to any of the ras oncogene family, and the identification of the gene(s) involved remains unresolved..$^{13}$ Other groups have examined normal human mesothelial cells and mesotheliomas to discern differences in expression of oncogenes encoding growth factors. ${ }^{14} 15$ These studies show increased RNA complementary to $\mathrm{c}-s i$, an oncogene encoding the $\beta$ chain plateletderived growth factor (PDGF), in mesotheliomas. Thus PDGF, a documented mitogen, may be important in conferring autonomous tumour growth.

Because most carcinogens are mutagens and conventionally regarded as genotoxic, much attention has focused on the mechanisms of DNA damage by asbestos. Unlike chemical carcinogens, asbestos fibres are not mutagenic in the Ames test, a bacterial assay designed to predict the mutagenic potential of various pollutants, or in other assays routinely used to evaluate mutagenicity. ${ }^{1617}$ The development, however, of a sensitive human-hamster hybrid cell assay that detects both point mutations and large deletions often lethal to normal cells has facilitated the detection of large, multilocus type lesions by chrysotile and crocidolite asbestos. ${ }^{1819}$ These results are important in that they may explain the mechanisms of asbestos induced genotoxicity leading to cell death of human mesothelial cells, a cell type extremely sensitive to the cytotoxicity of asbestos by comparison with other cells of the respiratory tract. ${ }^{20}$ Moreover, these data may be more relevant to the explanation of asbestos mediated cytotoxicity (as opposed to carcinogenicity) as multilocus deletions may not be compatible with cell survival and are implicated in cell damage by a variety of chemicals and ionising radiation. ${ }^{21}$

The mechanisms of asbestos mediated mutagenicity have recently been explored with human lymphocytes in whole blood. ${ }^{22}$ In these experiments, chrysotile asbestos, a zeolite mineral and latex particles increased the frequency of chromosomal aberrations in cultured lymphocytes. Because particulates caused increased generation of active oxygen species in peritoneal macrophages and genetic changes were inhibited by antioxidant enzymes (superoxide dismutase and catalase) and the iron chelator, rutin, genotoxicity was attributed to active oxygen species either generated during phagocytosis of particulates by monocytes in whole blood or catalysed by iron. These results illustrate the importance of using inert or non-carcinogenic particles, such as latex, as controls in experimental work with asbestos and the difficulties in equating particle induced mutagenicity in vitro with carcinogenic potential.
The work cited and recent work by Lund and Aust $^{2324}$ and others (reviewed in ${ }^{25}$ ) support an ever increasing data base acknowledging the importance of active oxygen species in carcinogenicity of asbestos. This hypothesis first stemmed from findings showing that cytotoxicity of asbestos preparations containing long $(>10 \mu)$ fibres could be prevented by antioxidant enzymes and other scavengers of active oxygen species whereas cytotoxicity of shorter fibres and glass was unaffected. ${ }^{26}$ Subsequent work has confirmed the importance of fibre length and geometry in the generation of active oxygen species by alveolar macrophageslonger, carcinogenic fibres (crocidolite, erionite) generate larger amounts of active oxygen species whereas short fibres and particles are relatively inactive. ${ }^{27}$ Some laboratory groups have reported that all types of asbestos cause generation of some active oxygen species in cell free systems via iron catalysed reactions on the fibre surface, thus revealing a second mechanism of generation of active oxygen species by asbestos. ${ }^{28} 29$ On a surface area basis, crocidolite is more catalytic than chrysotile. ${ }^{30}$ The presence of iron seems to be a critical and necessary factor in asbestos induced cytotoxicity, ${ }^{31}$ lipid peroxidation, ${ }^{32-34}$ and DNA breakage. ${ }^{24,32,35}$ Moreover, chelation and subsequent mobilisation of iron from asbestos enhances its biological effects in vitro ${ }^{23}$ and might, in the case of amphibole types of asbestos, occur over the protracted period of tumour development in vivo. A comparison of the chemical composition of chrysotile $\left(\mathrm{Mg}_{6} \mathrm{Si}_{4} \mathrm{O}_{10}(\mathrm{OH})_{8}\right)$ and the amphiboles, crocidolite $\left(\mathrm{Na}_{2}\left(\mathrm{Fe}^{3+}\right)_{2}\left(\mathrm{Fe}^{2+}\right)_{3} \mathrm{Si}_{8} \mathrm{O}_{22}(\mathrm{OH})_{2}\right)$ and amosite $\left((\mathrm{Fe}, \mathrm{Mg})_{7} \mathrm{Si}_{8} \mathrm{O}_{22}(\mathrm{OH})_{2}\right)$, shows that the iron content of crocidolite (about $36 \%$ of weight) is substantially increased by comparison with amounts in chrysotile (only $2 \%-3 \%$ in some chrysotile samples). ${ }^{36}$ Therefore, the decreased amounts and bioavailability of iron in chrysotile fibres may render them less biologically active over time.

Whereas both chrysotile and amphibole types of asbestos cause chromosomal alterations in rodent and human mesothelial cells in culture, ${ }^{2037}$ bronchial epithelial cells seem to be more resistant to the genotoxic and cytotoxic effects of asbestos. ${ }^{20} 3839$ Accordingly, asbestos seems to have more of a cocarcinogenic and promoter-like role in the development of lung cancer (reviewed in ${ }^{5}$ ). By contrast, chemical carcinogens in cigarette smoke cause damage to DNA by multiple mechanisms consistent with their classification as initiators of carcinogenesis.

Although others have suggested from epidemiological data that asbestos also functions primarily as a tumour promoter in mesothelioma, ${ }^{40}$ the molecular mechanisms of asbestos induced tumour promotion, a phenomenon involving chronic cell 

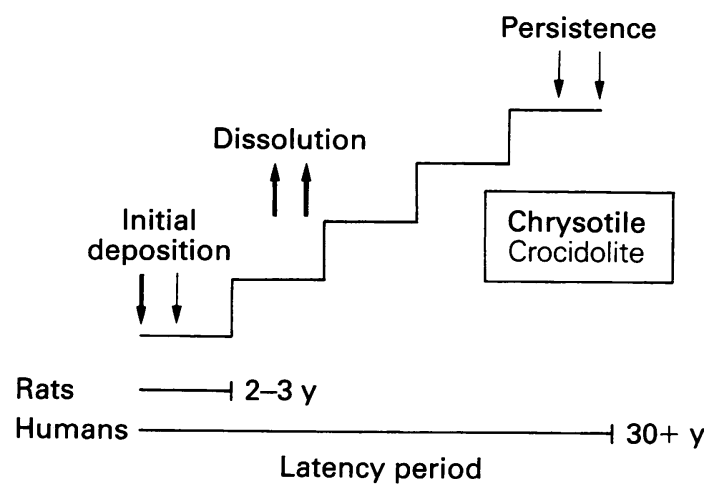

Tumour development by crocidolite and chrysotile asbestos in humans and rodents. Steps represent a series of proliferative alterations required for tumour promotion and progression to malignancy over the latency period of disease.

proliferation, have only recently been investigated. ${ }^{41}$ In studies from our laboratory, we focused on the induction of oncogenes (c-fos, c-jun) implicated in the control of cell division in cultures of rodent mesothelial cells exposed to crocidolite or chrysotile asbestos. These genes encode protein complexes that interact with DNA sequences regulating gene transcription, and are thought to participate in the pathways that control entry of cells into the $S$ phase of the cell cycle. ${ }^{42}$ The increases in c-fos and c-jun gene expression by asbestos in mesothelial cells are dose dependent and indicate a threshold response in that increases in protooncogenes are not seen at the lowest concentrations of fibres tested. Changes are most pronounced with crocidolite asbestos and are not seen with non-asbestos fibres or chemically similar particles. More importantly, induction of c-fos and c-jun by asbestos persists for many hours unlike the rapid and transient increases with many classical tumour promoters.

The persistent stimulation of cell division by asbestos in mesothelial cells of the respiratory tract suggests a model of carcinogenesis in which "mitogenesis increases mutagenesis" as rapidly dividing cells are more susceptible to DNA damage. ${ }^{43}$ Moreover, it provides a mechanistic framework for support of the concept that increased and chronic cell division is a controlling factor in many human cancers including mesothelioma. ${ }^{44}$ Although our recent work showing persistent protooncogene activation by asbestos illustrates one pathway of asbestos induced cell proliferation, other experiments show that additional mechanisms of cell proliferation may be important. For example, crocidolite and chrysotile asbestos, as well as long non-asbestos fibres, stimulate biosynthesis of polyamines, growth regulatory nuclear molecules that must accumulate in cells for cell division to occur. ${ }^{45}$ This seems to be an oxidant dependent phenomenon as antioxidants block asbestos mediated responses. ${ }^{46}$ Moreover, it has been well documented that cytotoxic concentrations of amphibole asbestos cause cell death, which then stimulates proliferation of surviving cells-that is, compensatory hyperplasia. ${ }^{47}$ These cellular responses are consistent with a chronically increased cell division model facilitating the accumulation of genetic errors during the process of tumorigenesis ${ }^{43} 44$

The figure presents a hypothetical construct of asbestos induced tumour development in humans that is consistent with the data presented and contemporary concepts of carcinogenesis. Moreover, it emphasises the important contributions of fibre durability and persistence as necessary factors in the development of tumours and provides a model to explain the increased pathogenicity of crocidolite in the development of mesothelioma. As described, crocidolite is an iron rich fibre by comparison with chrysotile. Crocidolite fibres are also less readily dissolved or broken down in the lung and are more apt to generate actual oxygen species by mobilisation of iron from the fibres over the extended latency period of tumour development. These iron catalysed reactions as well as generation of actual oxygen species from cells of the immune system in response to long needle like crocidolite fibres may be responsible for both the proliferative and DNA damaging effects of asbestos. By contrast, chrysotile undergoes dissolution in the lung and in pleural mesothelial cells, ${ }^{48}{ }^{49}$ and may not persist in human lungs over the extended period necessary for the development of tumours. The biodegradation of chrysotile is probably minimal over the time frame of development of rodent tumours (two to three years), thus accounting for the absence of striking differences in tumour incidence caused by various types of asbestos in rodent models of carcinogenesis. ${ }^{50}$

Dr Mossman's research is currently supported by grants from the National Heart, Lung, and Blood Institute (HL 14212, HL 39469) and a grant from the Environmental Protection Agency. Ms Barbara Cady and Ms Judith Kessler provided excellent technical assistance in the preparation of the manuscript. Dr Nicholas Heintz and Dr Christopher Wagner provided helpful editorial comments.

BROOKE T MOSSMAN

Department of Pathology,

University of Vermont College of Medicine,

Burlington, VT 05405, USA

1 Wagner JC. The discovery of the association between blue asbestos and mesotheliomas and the aftermath. $\mathrm{Br} \mathcal{F}$ Ind Med 1991;48:399-403. 
2 Health Effects Institute-Asbestos Research. Asbestos in public and commercial buildings: a literature review and synthesis of current knowledge. Cambridge, Mass; HE1, 1991.

3 American Thoracic Society. Health effects of tremolite. Am Rev Respir Dis 1990;142:1453-8.

4 McDonald AD, McDonald JC. Epidemiology of malignant mesothelioma. In: Antman K, Aisner J, eds. Asbestos-related malignancy. Orlando: Grune and Stratton, 1987:31-55.

5 Mossman BT, Bignon J, Corn M, Seaton A, Gee JBL. Asbestos: scientific developments and implications for public policy. Science 1990;247:294-301.

6 Brand KG. Foreign body induced sarcomas. In: Becker FF, ed. Cancer: a comprehensive treatise. Etiology: chemical and physical carcinogenesis. New York: Plenum Press, 1975:485-511.

7 Popescu NC, Chahinian AP, DiPaolo JA. Nonrandom chromosome alterations in human malignant mesothelioma. Cancer Res 1988;48:142-7.

8 Hagemeijer A, Versnal MA, Van Drunen E, et al. Cytogenetic analysis of malignant mesothelioma. Cancer Genet Cytogenet 1990;47:1-28.

9 Gibas Z, Li FP, Antman KH, Bernal S, Stahel R, Sandberg AA. Chromosome changes in malignant mesothelioma. Cancer Genet Cytogenet 1986;20:191-201.

10 Cote RJ, Jhanwar SC, Novick S, Pellicer A. Genetic alterations of the $p 53$ gene are a feature of malignant mesotheliomas. Cancer Res 1991;51:5410-6.

11 Iggo $R$, Gatter $K$, Bartek J, Lane D, Harris AL. Increased expression of mutant forms of $p 53$ oncogene in primary lung cancer. Lancet 1990;335:675-9.

12 Metcalf RA, Welsh JA, Bennett WP, et al. p53 and Kirsten-ras mutations in human mesothelioma cell lines. Cancer Res 1992;52:2610-5.

13 Barrett JC, Lamb PW, Wise RW. Multiple mechanisms for the carcinogenic effects of asbestos and other mineral fibers. Environ Health Perspect 1989;81:81-9.

14 Gerwin I, Lechner JF, Reddel RR, et al. Comparison of production of transforming growth factor- $\beta$ and platelet-derived growth factor by normal human mesothelial cells and mesothelioma cell lines. Cancer Res 1987;47:6180-4.

15 Versnel MA, Hugemeijer A, Bouts MJ, van der Kwast TH, Haagsteden HC. Expression of c-sis (PDGF- $\beta$ chain) and PDGF- $\alpha$ chain genes in ten human malignant mesothelioma cell lines derived from primary and metastatic tumors. Oncogene 1988;2:601-5.

16 Chamberlain M, Tarmy EM. Asbestos and glass fibres in bacterial mutation tests. Mutat Res 1977;43:159-64.

17 Shelby $M D$. The genetic toxicity of human carcinogens and its implications. Mutat Res 1988;204:3-15.

$18 \mathrm{Hei}$ TK, Piao CQ, He Zy, Vannals D, Waldren CA Chrysotile fiber is a strong mutagen in mammalian cells. Cancer Res 1992;52:6305-9.

19 Hei TK, He Zy, Piao CQ, Waldren CA. The mutagenicity of mineral fibers. In: Brown RC, Hoskins JA, Johnson NF, eds. Mechanisms in fibre carcinogenesis. New York: Plenum Press, 1990:319-25.

20 Lechner JF, Tokiwa T, LaVeck M, Benedict WF, et al. Asbestos-associated chromosomal changes in human mesothelial cells. Proc Natl Acad Sci USA 1985;82:3884-8.

21 Waldren CA. Mutational analysis in cultured human hamster hybrid cells. In: deSorres FJ, ed. Chemical mutagens: principles and methods for their detection. New York: Plenum Press, 1983:235-47.

22 Korkina LG, Durnev AD, Suslova TB, et al. Oxygen radical mediated mutagenic effect of asbestos on human lymphocytes: suppression by oxygen radical scavengers. Mutat Res 1992;265:245-53.

23 Lund LG, Aust AE. Iron-catalyzed reactions may be responsible for the biochemical and biological effects of asbestos. BioFactors 1991;3:83-9.

24 Lund LG, Aust AE. Iron mobilization from crocidolite asbestos greatly enhances crocidolite-dependent formation of DNA single-strand breaks in $\Phi \times 174$ RFI DNA. Carcinogenesis 1992;13:637-42.

25 Kamp DW, Graceffa P, Pryor W, Weitzman S. The role of free radicals in asbestos-induced diseases. Free Rad Biol Med 1992;112:673-720.

26 Mossman BT, Marsh JP, Shatos MA. Alteration of superoxide dismutase activity in tracheal epithelial cells by asbestos and inhibition of cytotoxicity by antioxidants. Lab Invest
1986:54:204-12.

27 Hansen K, Mossman BT. Generation of superoxide $\left(\mathrm{O}_{\overline{2}}^{\overline{2}}\right)$ from alveolar macrophages exposed to asbestiform and nonfibrous particles. Cancer Res 1987;47:1681-6.

28 Gulumian M, Van Wyk JA. Hydroxyl radical production in the presence of fibers by a fenton type reaction. Chem Biol Interactions 1987;62:89-97.

29 Weitzman SA, Graceffa P. Asbetos catalyzes hydroxyl and superoxide radical generation from hydrogen peroxide. Arch Biochem Biophys 1984;228:373-6.

30 Jolicoeur C. Presentation at NATO-NIH workshop. Effects of mineral dusts on cells, Sherbrooke, Quebec: NATO-NIH 1988.

31 Shatos MA, Doherty JM, Marsh JP, Mossman BT. Prevention of asbestos induced cell death in rat lung fibroblasts and alveolar macrophages by scavengers of active oxygen species. Environ Res 1987;44:103-16.

32 Turver CJ, Brown RC. The role of catalytic iron in asbestos induced lipid peroxidation and DNA-strand breakage in C3H10T1/2 cells. Br F Cancer 1987;56:133-6.

33 Weitzman SA, Weitberg AB. Asbestos-catalysed lipid peroxidation and its inhibtion by desferrioxamine. Biochem $f$ 1985;225:259-62.

34 Goodlick LA, Pietras LA, Kane AB. Evaluation of the causal relationship between crocidolite asbestos induced lipid peroxidation and toxicity to macrophages. Am Rev Respir Dis 1989;139:1265-73.

35 Kasai $\mathrm{H}$, Nishimura S. DNA damage by asbestos in the presence of hydrogen peroxide. Gan To Kagaku Ryoho 1984;75:841-4.

36 Timbrell V. In: Shapiro HA, ed. Pneumoconiosis: proceedings of the international conference. Johannesburg, Cape Town: University Press, 1970;28-36.

37 Jaurand MC, Kheuang L, Magne L, Bignon J. Chromosome changes induced by chrysotile fibers and benzo-3,4-pyrene in rat pleural mesothelial cells. Mutat Res 1986;169:141-8.

38 Fornace AJ Jr, Lechner JF, Grafstrom RC, Harris CC. DNA repair in human bronchial epithelial cells. Carcinogenesis 1982;3:1373-7.

39 Mossman BT, Eastman A, Landesman JM, Bresnick E. Effects of crocidolite and chrysotile asbestos on cellular uptake, metabolism and DNA after exposure of hamster tracheal epithelial cells to benzo(a)pyrene. Environ Health Perspect 1983;51:331-8.

40 Browne $\mathrm{K}$. Asbestos-related mesothelioma: epidemiological evidence for asbestos as a promoter. Arch Environ Health 1983;38:261-6.

41 Heintz NH, Janssen YM, Mossman BT. Persistent induction of c-fos and c-jun protooncogene expression by asbestos. Proc Natl Acad Sci USA 1993;90:3299-303.

42 Angel $\mathrm{P}$, Karin M. The role of jun, fos and the AP-1 complex in cell-proliferation and transformation. Biochimi Biophys Acta 1991;1072:129-57.

43 Ames BN, Gold LS. Mitogenesis increases mutagenesis. Science 1990;249:970-1.

44 Preston-Martin S, Pike MC, Ross RK, Jones PA, Henderson $B E$. Increased cell division as a cause of human cancer. Cancer Res 1990;50:7415-21.

45 Marsh JP, Mossman BT. Mechanisms of induction of ornithine decarboxylase activity in tracheal epithelial cells by asbestiform minerals. Cancer Res 1988;48:709-14.

46 Marsh JP, Mossman BT. Role of asbestos and active oxygen species in activation and expression of ornithine decarboxylase in hamster tracheal epithelial cells. Cancer Res 1991;51:167-73.

47 Mossman BT, Craighead JE, MacPherson BE. Asbestosinduced epithelial changes in organ cultures of hamster trachea: inhibition by retinyl methyl ether. Science 1980; 207:311-3.

48 Jaurand MC, Bignon J, Sebastien P, Goni J. Leaching of chrysotile asbestos in human lungs. Correlation with in vitro studies using rabbit alveolar macrophages. Environ Res 1979;14:245-54.

49 Jaurand MC, Gaudichet A, Halpern S, Bignon J. In vitro biodegradation of chrysotile fibres by alveolar macrophages and mesothelial cells in culture: comparison with a pH effect. Br F Ind Med 1984;41:389-95.

50 Wagner JC, Berry G, Skidmore JW, Timbrell V. The effects of the inhalation of asbestos in rats. $B r f$ Cancer 1974; 28:250-69. 